\title{
Dante in Mogadishu: The Divine Comedy in Nuruddin Farah's Links
}

This article aims to explore the complex network of intra-textual and intertextual references to Dante's The Divine Comedy in Nuruddin Farah's novel Links (2005). By analyzing the quotations from the poem, this essay wishes to show how the Comedy informs the novel at various levels, from the paratext (since Dante's tercets from Inferno are chosen as an epigraph) to the text itself (since Inferno appears to be deeply constitutive of Links). The analysis then suggests that, on the one hand, Farah employs Dante's poem to address, represent and understand the civil-war context of Somalia from the protagonist's point of view. On the other, he subverts and re-contextualizes Inferno to create new meanings and to distance his novel from Dante's literary antecedent. Therefore, by analyzing the practices of intertextuality between the two texts, this essay aims to investigate both the converging and conflicting strategies enabled in the novel. Keywords: Farah, Dante, Mogadishu, intertextuality, re-contextualization, paratext, epigraph.

\section{Introduction}

In Nuruddin Farah's Links (2005), a particular element of the paratext, the epigraph, is exceptionally rich. It is made up of twelve quotations by four different authors, and it establishes a multilayered relationship between the plot of the novel, its protagonist, and the intertexts, i.e. the sources of the epigraphs. There are several intertextual resonances between the novel, the protagonist and Dante Alighieri's La Divina Commedia (The Divine Comedy). Dante's Inferno, in particular, can be considered as the major source of signification for the novel, as it "appears to be part of the mental universe" of the protagonist (Moolla 158-9). Therefore, to read Links without it would mean to diminish the novel's significance.

This article then proposes an investigation of how Farah's intertextual practices work between Links and the Comedy. First, by cross-reading the novel and the poem, the analysis attempts to shed light on the specificity of Farah's employment and understanding of the Comedy. Second, it wishes to examine the host of multilayered relations and practices uniting the two texts built upon Dante's representation of Hell. In the Comedy, the Florentine poet recounts the speaker's allegoric journey through the three realms, to which he commits three canticles: Inferno (Hell), Purgatorio (Purgatory), and Paradiso (Paradise). By employing the interlocking three-line rhyme scheme called terza rima, the Comedy provides a comprehensive overview of the knowledge of the Middle Ages, but also offers an understanding of Dante's worldview and vast erudition about literature, politics and religion. Born in Florence in 1265 and expelled from his city due to political reasons, Dante spent his life in exile until his death in 1321, after years of wandering and unceasing writing; in exile, he conceived most of his literary production, including his preeminent work, The Divine Comedy.

The presence of exile emerges as an apparent association between Dante and the protagonist of Links, the diasporic Somali Jeebleh, who fled Mogadishu at the outbreak of the civil war to settle in the United States. Moreover, it recalls Farah's life, as he began an exile that would last for 22 years after being warned by the Somali government that he would be arrested over the content of his novel, A Naked Needle (1976). In Links, however, Farah does not uphold this association explicitly, thus leaving the shared biographical aspect of exile in the background. Links, in fact, is a novel about homecoming and describes the experience of Jeebleh's return home, rather than his

Marco Medugno is a PhD candidate and teaching assistant in the School of English Literature, Language and Linguistics at Newcastle University, Newcastle upon Tyne, United Kingdom.

Email: m.medugno2@newcastle.ac.uk

(D) https://orcid.org/0000-0001-8986-8268

DOl: dx.doi.org/10.17159/2309-9070/tvl.v.57il.8060

DATES:

Submitted: 27 May 2019; Accepted: 4 July 2019; Published: 28 April 2020 
life in New York as an expatriate. As Fiona Moolla has rightly noticed, Links overturns the grounding premise of the Comedy: "Dante the Pilgrim descends into Hell and discovers that it looks remarkably like his native Florence. Jeebleh, by contrast, returns to his native Mogadiscio and discovers that it looks remarkably much like Hell" (158). Moolla's observation about the two texts clearly points out that Farah does not aim to rewrite the Comedy. Accordingly, there are no systematic correspondences, for example, between the poem and the novel in terms of structure: while the Comedy is divided into three canticles consisting of 33 cantos (34 in Inferno), Links is made up of four parts and an epilogue, for a total of 31 chapters. The plot itself does not reflect Dante's symbolic journey through the three realms of the dead, nor does it embrace its allegorical scope. Ultimately, Farah jettisons several of the pivotal assumptions grounded in Dante's medieval ethos, drawing upon Christian theology and Thomistic philosophy, such as the ubiquitous role of God, the divine and rational order of the afterworld and the logic of contrapasso, i.e. the principle by which punishments are assigned. Despite this divide, the Comedy represents the primary literary source that triggers a process of intertextuality. According to the French theorist Gérard Genette, the latter notion, multiple and split, does not represent only "a relationship of co-presence of one text within another" (Palimpsests 1), but it engages with a series of different practices within the variable system of textual analysis and interpretation. In the case of Links, as Lorenzo Mari appropriately suggests, Farah employs intertextuality as a means to build a metaphorical-metonymic conversation between the poem and the novel through some extra-textual elements, such the epigraphs, which are significant for its in-depth interpretation (103).

The focus of this article is to show that the complex intertextual network should certainly be investigated, as Mari indicates, as a dialogue between the novel and the poem, but from the protagonist's point of view. More specifically, the Comedy provides the lens through which the war-torn setting of Mogadishu and Somalia is portrayed in the novel, and it also rises as a powerful diegetic device to support the protagonist's point of view, the latter being a Dante scholar. Indeed, Jeebleh looks at Inferno as his principal source to unravel the complex skein of Somalia's reality, to grasp the events he witnessed, and to describe the characters he met during his journey. However, this process occurs at two different levels, namely that of the author and that of the protagonist. Indeed, on the one hand, Farah supports his protagonist's analytical understanding of Mogadishu's civil war by fostering a parallel between the latter and medieval Florence through Dante's Inferno. On the other hand, he implies a degree of incommensurability between his novel and the poem by suggesting the limits of Jeebleh's perspective based on Dante's references. This practice can be retrieved in the Comedy as well: in the poem, even though the author is the protagonist, Dante the poet distances himself from the character; in Links, this distance is paralleled (or recalled) by Farah's attitude towards his protagonist, both to underscore the latter's limited perspective and to endow him "with sufficient voice to express an understanding, particular to [him], of what it means to be human and to play roles in human communities" (Alden and Tremaine 161). In other words, the tercets from Inferno aim to give, from the protagonist's point of view, "shape and significance to the immense panorama [...] of anarchy" into which Mogadishu and Jeebleh are plunged (Eliot 483). Drawing upon the imaginative richness of Dante's poem, the protagonist deciphers and interprets his experiences in the city. Farah fosters this view by weaving a multilayered thread of intratextual and intertextual connections, both allusive and explicit. At the same time, I argue, Farah also disturbs the rationale behind Jeebleh's interpretation. He prompts the readers to place his novel against the backdrop of Dante's poem, by using the latter as the primary literary resource to structure Links and Jeebleh's "mental universe" (Moolla 159), but he also distances himself from the Comedy, thus attesting its insufficiency to represent the actualities of Somalia's condition. The following analysis will show how this double strategy occurs, and how Farah both articulates similarities and parallels with Inferno, but also unsettles his protagonist's understanding by implying his one-sidedness. Specifically, Farah reveals that Dante's view is partially incomplete and inadequate to understand the realities of Somalia unless one employs different practices of intertextuality; this article aims to examine mainly three of them, namely subversion, simplification, and re-contextualization, which can be considered as key practices to elucidate the relationship between the Comedy and Links.

The choice of the Comedy as the primary intertext, at this point, could appear unclear due to the apparent differences and the necessity to modify and adapt it. However, I argue that Farah's choice to draw on Dante's poem relies on its ability to cross time, space and language through its eschatological scope and universal claim. Pascale Casanova notes how Dante has come to represent one of the universal classics. These classics, once canonized, "lose a part of their historical context and, as a result, a part of their power of subversion" (328). However, later authors such as Joyce and Beckett have retrieved this power, since they were able to put the classics "to new and specific uses" (Casanova 328). Accordingly, Farah turns the Comedy to his own advantage and, to rephrase Casa- 
nova, employs it to the new and specific context of Somalia. He finds in Inferno a rich set of imaginative resources and visionary images that help him to represent, dramatize and reflect on a present-day condition that resembles an infernal experience. In the case of Links, Farah does not look at Dante's subversive power concerning his linguistic and literary project, as Casanova suggests, but considers Dante in relation to his ability to intertwine universal aspects with the local context of medieval Florence. By invoking a universal and human condition of suffering, Farah resolves the complete separation between the two texts and fosters their intertextual link. Accordingly, Farah does not provide a close reading of the poem, denoting a lack of philological interest in retrieving the original political and historical context of Dante's times (Mari 102). As well, instead of reclaiming the theological, teleological, and allegorical scope of the Comedy, Farah shows interest in Dante's fictionalizations of the relationship between humans in an ill-fated time of grief and sorrow. Therefore, the following intertextual analysis aims to stress "interpretation rather than [...] the establishment of particular facts" between the poem and the novel, in order to retrieve and examine "the cultural codes which are realized (and contested) in texts" (Frow 46).

\section{Farah and Dante between exile and translation}

Before examining Farah's interpretative process in the Comedy, I wish to highlight three aspects of the novel concerning the theme of exile, the narrator and the edition of the poem used by Farah. Concerning the first aspect, Jeebleh shares with Dante (and with Farah) the same condition of exile, as noticed by Moolla (158). However, as the analysis will clarify, the quotations from Dante's poem never refer to this biographical connection, thus leaving the shared feature of exile in the background. Farah aims, instead, creatively to employ the visionary and symbolic force of Inferno for investigating and representing Somalia's hard reality. On the one hand, by presenting the Somali civil war as a modern-day Hell along with the paired comparison between Dante's Florence and Inferno, Farah suggests a profound interconnection between past and present, but also between Italy and Somalia, along with a transnational and trans-historical analogy. On the other hand, Farah emphasizes the need for a re-contextualization, suggesting that his intertext is also partly inadequate to the task of wholly describing Somalia's contemporary reality. This latter aspect surfaces due to the high degree of re-contextualization, but also in a network of intertextual links that encompass several other references to, for example, Somali folktales, American television news, newspapers, films, Irish fables and the Koran. In other words, "Although Dante's Inferno constitutes a prominent literary intertext of Links, the latter also integrates references to media representations of the war, in a way deploying them as another subtext" (Mzali 95).

While the protagonist recognizes in Mogadishu an earthly Hell drawn upon Dante's description of the netherworld, Farah implies that this perspective is confined to Jeebleh's point of view. Indeed, different characters may have engaged with a diverse representation of Mogadishu, derived from their own beliefs and vision of the afterlife. For example, in a dialogue of the novel, Farah explores three different ideas of Hell according to Jeebleh, Bile and their friend Seamus (Links 57). The first, as shown, shares Dante's imaginative creation unfolded in Inferno, building a bridge between the representational level of the fictional character and the paratextual element supplied by the author. The second, Bile, draws his interpretation from the Koran, which enables a relationship between 'Hell' and 'fire', and lastly, Seamus argues that Hell should be considered as "a state of mind" by telling an Irish fable (57). This example, along with the limited third-person narrator, who provides the reader with the thoughts and actions of the protagonist alone, further supports the understanding of the novel as predominantly focused on Jeebleh's point of view. He is the focal character and always appears on the scene, so that the events of the plot are described through his perception; the reader, then, comes to know about the offstage actions when and if other characters tell them to Jeebleh once they have happened. The Comedy surfaces as a bridge between the "mental universe" of Jeebleh and that of the reader, via intertextual and intratextual practices (Moolla 158). The reader, in turn, plays an active role in unraveling this multilayered intertextuality made up of allusions, subversions and recontextualizations.

An example of how the Comedy occupies the mental universe of Jeebleh may be found in the passage of the novel, also pointed out by John Masterson (153), when the protagonist states: "I recited a verse from Dante's Inferno, in which enslaved Somalia was a home of grief, a ship with no master that was floundering in a windstorm" (Links 193). To be precise, these metaphors have a different source: while "a home of grief" is the translation of "doloroso ospizio" in Inferno (Canto V, 16), the image of the ship is taken from Purgatory (Canto VI, 77) and translates the line: "Nave senza nocchiere in gran tempesta" (ship without a helmsman in harsh seas). According to Mari, the reference 
to Purgatorio can also be read as Farah's attempt to "further deconstruct the neocolonial imagery of failed nations as exclusively related to the post-colonial koine" (106). In other words, Farah analogizes Somalia to Italy via the metaphorical use of the "home of grief" and the ship left adrift, so to debunk the idea that the concept of "failed nation" can be applied only to postcolonial countries. This trans-historical analogy supports the argument that Farah employs the Comedy as a source that allows him to develop a universalizing process: by drawing a parallel between thirteenth-century Italy and contemporary Somalia, Farah points out the joint historical trajectories occurred by both the metropole and the so-called colonial periphery.

Finally, the third aspect concerns the issue of language. Farah employs Allen Mandelbaum's English translation of the Comedy, instead of the original Italian version, as he acknowledges in the final "Author's note" (335). The choice of using the translation, despite knowledge of the Italian language by both Farah and the protagonist, seems to overshadow the role of Dante as a former colonial author. The latter term, in this case, should be understood as a reference to the Italian canonical authors who were employed in the "colonial" education in Somalia, as well as during the Italian trusteeship administration (1950-60). Indeed, as Ali A. Abdi has noticed, "one of the first formal colonial schools operating in Somalia was opened by the Italian Dante Alighieri Society in 1907 to teach Somali children the Italian language" (331). However, in Links, Farah minimizes this scholastic role of Dante, avoiding any specific reference to the presence of the Tuscan poet in the colonial educational system, as instead explicitly highlighted by other Somali authors, such as Garane Garane in his novel Il latte è buono (47). As the following analysis will show, Farah focuses his attention on how the Comedy represents both Jeebleh's affiliation to Italian culture and as a diegetic device to provide the symbolic background to read Mogadishu through the eyes of his protagonist. More than a colonial author imposed by the former Italian cultural supremacy in Somalia, Dante appears as a transnational model to represent human suffering, along with an extensive tradition of authors who have re-actualized and re-interpreted the Comedy, such as James Joyce, T. S. Eliot, Primo Levi, Osip Mandelstam and Derek Walcott. This universalizing feature of the poem is then the shared starting point to trigger the following intertextual analysis, focused on the particular and personal approach employed by Farah to adapt the Comedy for his purpose.

Concerning the epigraph, Genette, in his essay Paratexts: Thresholds of Interpretation (1997), defines the epigraph as "a quotation placed en exergue, generally at the head of a work or a section of a work" (144). In Links, the corpus of quotations of the epigraph section may be divided into two groups, according to the source, location, and function. Farah places three quotations from different authors before the title and after the dedication:

If you don't want to be a monster, you've got to be like your

fellow creatures, in conformity with the species, the image of

your relations. Or else have progeny that make you the first

link in the chain of a new species. For monsters do not

reproduce.

MICHAEL TOURNIER

\begin{abstract}
The individual leads in actual fact a double life, one in which he is an end to himself and another in which he is a link in a chain which he serves against his will or at least independently of his will.

SIGMUND FREUD
\end{abstract}

A dog starved at his master's gate

Predicts the ruin of the state!

WILLIAM BLAKE

I argue that Tournier's, Freud's and Blake's functions are "of commenting — sometimes authoritatively—and thus of elucidating and thereby justifying not the text but the title" (Paratexts 156). Also, they disclose the identity struggle of the protagonist, but they do not reappear as intratextual references, and they do not seem to belong to the imaginative universe of the characters. Even though interesting, they are beyond the scope of this paper and, thus, they will not be discussed here. The quotations with a higher "illocutionary force" (Paratexts 1) are, in fact, those from Dante, which represent the primary subject of this analysis. They are all taken from Inferno, and they share the same position, being located before each of the four parts and the epilogue. 


\section{Quoting from Inferno: A Somali civil war re-contextualization}

Farah sets Links in the middle of the conflict that broke out after Siyad Barre's fall in 1991, when armed factions began competing for authority in the power vacuum. Two rival warlords, Mohamed Farah Aidid and Ali Mahdi Muhammad, whose real names are replaced by the monikers Strongman North and Strongman South, fight to control their respective zones. At the time of the story, Mogadishu is the battleground where a disastrous war of power-deemed an ethnic conflict-extinguishes any form of public services, social practices and sense of community. Citizens live in the Hobbesian condition of bellum omnium contra omnes, namely the "continual fear, and danger of violent death" (Hobbes 83). Additionally, United Nations forces, chiefly led by the Americans, increase the fighting, embroil civilians in the conflict and galvanize the rivalry between different factions.

The protagonist Jeebleh, a Somali professor who lives in New York, returns to his native Mogadishu after twenty years of exile to visit his mother's grave. However, he rapidly becomes involved in a rescue operation, after Raasta, the niece of his childhood friend Bile, has been kidnapped. Farah describes this "murky present" (113) of warfare by employing the rich imaginary of The Divine Comedy as the primary intertextual source to portray Jeebleh's journey through Mogadishu, which can be considered a secularized version of Hell. In order to examine the intertwined practices of subversion, simplification, allusions and re-contextualization, I suggest looking at the first four epigraphic quotations from Dante's Inferno placed before Part 1 . The first is made up of the lines 1-3 of Canto III (Links 1):

Through me the way into the suffering city,

Through me the way to the eternal pain,

Through me the way that runs among the lost.

These words are engraved on the gate of Hell, as they appear to Dante the pilgrim and the Latin poet Virgil, his reliable and sage guide through the netherworld and the embodiment of reason (Alighieri XXII). In Part l, Jeebleh is represented at the beginning of his journey, as he has just landed on an airstrip nearby Mogadishu and waits for a lift to the city. The first Dantean allusion is suggested by Jeebleh himself, who refers to the capital of Somalia (written with the Italian spelling Mogadiscio) as "a place of sorrow" and as "the city of death", directly rephrasing Dante (Links 5, 70).

Farah then stretches another allusion when introducing the character of Af-Laawe, who appears as a shadow, like Virgil when he materializes in the first meeting with the pilgrim (Links 4; Moolla 158). Jeebleh himself supports this allusion further by noticing that Af-Laawe's name means "the one with no mouth" and that, "to a Dante scholar" it "might allude to the Inferno" (Links 23). However, the latter correspondence remains obscure. As in the case of the metaphors of the ship and the house, Dante is used by Jeebleh almost inaccurately or without precise references. This imprecision supports the fact that Farah is not interested in a philological rewriting of the Comedy, and that Jeebleh himself uses Dante's lines to describe the Somali context loosely. Mari suggests that, in fact, Af-Laawe represents the "negative parody" of Virgil and that his name refers to the dictator, Muhammed Siyad Barre, whose nickname was Afweyne (Big mouth) (104). However, starting from this interpretation, a reader who is familiar with the poem may spot another similarity, namely, that between Af-Laawe and Charon, the mythological boatman who ferries souls across the river Acheron. As in the Comedy, Af-Laawe does not drive Jeebleh to the city and he only manages to organize a lift for him, similar to Charon's role as psychopomp, who withholds from Dante, being a living body, a trip in his boat. In the poem, the crossing of the river Acheron is left undescribed, since Dante faints, waking up on the other side, at the beginning of the next canto. The comparison between the mythological ferryman and Af-Laawe is also reinforced, as the latter is presented as transporting the corpse of a ten-year-old boy, senselessly murdered at the airport, in his funeral vehicle (Links 18).

The same uncanny resemblance and degree of uncertainty also affect the analogy with Virgil. In fact, the latter has no direct equivalent in Links. Since no one can be trusted, because lies are the norm in a city where friendship, family, loyalty, betrayal, violence and hatred are complex terms, Jeebleh cannot be wisely guided through Mogadishu. Besides, "distrust was the order of the day, and everyone was suspicious of everybody else" (51). The ubiquitous presence of conspiracy and machination suggests one of the causes at the heart of the civil war: "the betrayal of one Somali by another" (Moolla 159). The last quotation of the epigraph further buttresses the cloak and dagger background of the novel: "They said he was a liar and father of lies." Dante, in Canto XXIII (line 144), employs this single-line periphrasis to describe Lucifer, but Farah discards the context of the canto and uses the fallen angel as a benchmark to refer to the former dictator Siyad Barre. As well as Lucifer, who is not mentioned 
in that line, Barre is a presentia in absentia, since his role and legacy are only implied (Mari 104). However, Farah shows that the dichotomy between good and evil, defined in the Comedy according to the Christian more code, does not subsist in the novel. Indeed, Links suggests that the characters are an amalgam of evil and good, polarized in two extremes: the antagonist warlord Caloosha, described as an evil monster, and Raasta, the miracle child. Bile himself-regarded as of the most reliable character-is suspected of murdering and robbing, thus spoiling his reputation as being a trustworthy person (Links 6-7).

The ethical framework in which Dante's Hell is inscribed, quite the reverse, is a rigid theological and philosophical scheme that sets the normative moral code to regulate how sinners should be punished. In Links, instead, whether Jeebleh explicitly places betrayal in the foreground to describe his fellow Somalis' behavior, Farah makes him a liar and a traitor in the first place. Jeebleh tells half-truths to his wife in New York regarding his business in Mogadishu (Links 178); Caloosha, the antagonist, repetitively calls him a liar (102) and implies that Jeebleh's mother may have died thinking him a traitor (237); finally, he "wouldn't hesitate to lie if he believed that by doing so he might serve a higher purpose" (48). This latter idea leads him, in the end, to even justify violence for the sake of justice (332). Farah then dramatizes how Jeebleh becomes progressively involved in the social and moral codes of the civil war, so that, "paradoxically, the quest for justice draws him closer and closer to the Devil" (Moolla 123). On the contrary, Dante's gradual proximity to the pit of Hell, where Lucifer dwells, does not correspond with his resulting moral corruption, since the poem allegorically represents the soul's journey towards God.

This attention placed on the human aspect, rather than on the dogmatic feature that underpins the poem, is retrieved in the epigraphic quotation from Canto III:

For we have reached the place ...

where you will see the miserable people

those who have lost the good of the intellect.

These lines (16-18) re-contextualize the lost souls of Hell as the inhabitants of Mogadishu, thus acquiring the function of "commenting on the text, whose meaning it indirectly specifies or emphasises" (Paratexts 157). Jeebleh himself, rephrasing Dante's words and stressing the intratextual references, describes his fellow Somalis as "dwelling in terrible misery" and as people who have lost their ability to "remain in touch with their inner selves" (Links 15, 70). The latter description paraphrases the word "intellect", but, again, Farah recontextualizes the term, distancing it from Dante's meaning: while, in the tercet, "intellect" means God or the Supreme Good (Sapegno 31), in the novel it denotes the capacity to choose between right or wrong, good or evil. The harsh judgement made by Jeebleh about Mogadishans further shrinks the spectrum of human feelings and reduces the inhabitants, due to the cruelty of the civil war, into non-human beings who, "living in such vile conditions, were bound to lose touch with their own humanity" (Links 201).

The third and last quotation of Part 1, from Inferno X, further underscores the symbolic association between the sinners' souls and the people of Mogadishu:

"Your accent makes it clear that you belong

among the natives of the noble city ..."

My guide — his hands encouraging and quick-thrust me between the sepulchers toward him

Saying ... "Who were your ancestors?"

Farah assembles the tercets himself by accurately choosing the lines of Canto X $(25-6 ; 37-9 ; 42)$ more suitable to highlight Jeebleh's struggle with his identity. To better elucidate this strong intertextual link, the more general discursive structure of Canto $X$ should be considered.

Dante and Virgil stand in the sixth circle, where open tombs engulfed by flames surround them. Here lie the heretics, meaning by heresy the "self-separation from that with which we should be connected (city, God, family, friends)" (Barolini, "Inferno 10"). This explanation echoes Jeebleh's expression referring to the inhabitants of Mogadishu, who lost the ability to live according to the rules of the society, and "showed little or no kindness to one another" (Links 201). In this regard, Farah relies on the translation "noble city" for "nobil patria" (noble homeland), overturning Dante's generic allusion into an explicit reference to the urban context. Mogadishans have restored ill-fated clan logics, and everyone has become suspicious of friendship, due to the primary importance assumed by blood affiliation. They "care[d] little about one another" and are affected by an "incurable apathy", thus stressing that, according to Jeebleh's point of view, Mogadishans are unable to either recognize or under- 
stand their fellows' sorrow (Links 237). Correspondingly, when in Canto X Dante stages a meeting with Farinata and Cavalcante de Cavalcanti, the two souls are described as self-centered and ignorant of each other's suffering (Musa 85). Concerning the epigraph and the dialogue with Farinata (the "him" in the quotation, a member of a noble family and a military leader of the Ghibellines), Farah transfers the meeting into the new context. In the Comedy, the meeting with Farinata allows Dante the poet to stage his affection for his place of origin, doomed by the conflict between the factions of White and Black Guelphs, the former supporting the Pope and the latter opposed to his influence. After the Guelphs defeated the Ghibellines, they began infighting. Dante was among the supporters of the White faction, thus causing his exile after the Black Guelphs took control of Florence. Similarly, Farah dramatizes Jeebleh's affection and nostalgia towards the cosmopolitan Mogadishu of the 1970s (Links 14, 35), but he shares with Dante the same distress and disillusionment at the destruction of the city due to fratricidal conflict. Farinata recognizes Dante the pilgrim thanks to his "accent", thus introducing another primary theme of Links, namely language.

Language, both in Inferno X and in Links, may be considered as a "weapon of choice" that can prevent any form of dialogue and hinder any real possibility of conversation (Barolini, "Inferno 10"). This negative feature stands out in the novel since Jeebleh often finds himself in the condition of being misunderstood, misinterpreted or even not listened to at all. For example, at the very beginning, he is overcome by the almost monologic conversation he holds with a driver nicknamed Major; the latter persistently questions Jeebleh's identity and overpoweringly articulates his opinions, while the protagonist tries to avoid answering him and remains "silent and sullen" (Links 26). Moreover, Jeebleh has difficulty in translating the Somali expression dagaalka sokeeye (killing an intimate) from his native tongue into English (137-8). He also struggles with the use of Somali pronouns, trapped in the uncertainty between "we" and "they" to denote Somalis in general or clans, respectively (Links 12, 41, 219). However, the most suitable example to clarify the relationship between "accent" and "belonging" can be retrieved in the words of Bile, Jeebleh's oldest friend:

In Somalia the civil war then was language [...] At one point, a couple of armed men flagged me down, and one of them asked, "Yaad tahay?" I hadn't realized that the old way of answering the question "Who are you?" was no longer valid. Now the answer universally given to "Who are you?" referred to the identity of your clan family, your bloody identity! (Links 119)

Bile's statement, after experiencing seven years of imprisonment because of his opposition to Barre's dictatorship, builds a cross-cultural and multilingual link between the question in the last line of the quotation from Inferno X: "Chi fuor li maggior tui?" (Who were your ancestors?) and the Somali sentence "Yaad tahay?" (Who are you?) as understood by Bile during the civil war. The puzzling question, as bewildering as the resulting strenuous quest for a proper answer, represents one of the key themes of the novel, since it concentrates the subject of clannism as tackled and deconstructed by Farah in Links (Mari 105). Indeed, Jeebleh, who feels "no clan-based loyalty himself-in fact, the whole idea revolted and angered him" (Links 11), cannot avoid being questioned about his origin by other characters, such as Major, Af-Laawe, his antagonist Caloosha, and by clan elders. In his only consultation with them, Jeebleh explicitly clarifies his opinion "of distrust of clan", continuously reiterated throughout the whole novel (Dodgson-Katiyo 70). Jeebleh's repulsion by clannism isolates him from the community and his fellow Somalis, recurrently described as assembled in crowds or mobs (Links 16, 96, 117, 130, 135, 195-200). As Dante the pilgrim is the only living body among the souls who often gather together in groups or flocks, Jeebleh is depicted as the only one who stands out from the crowd. This same difference is ironically alluded to in Links: "What distinguished [Jeebleh] from the men in the crowd, apart from the fact that he had neither a club nor a firearm, was that they were all wearing sarongs. He had on trousers" (196). Also, the protagonist's name suggests his singularity, meaning "the one with pockets" (95). This distinctive feature, which underlines the physical dissimilarity of Jeebleh, also allusively foreshadows the incommunicability with his fellow Somalis.

The recurrent presence of crowds leads us to the first quotation of Part 2, assembled by Farah himself, taking lines 16, 19-20, 22-3 and 26 from Canto XIV (Links 147):

O vengeance of the Lord ...

I saw so many flocks of naked souls,

all weeping miserably ...

Some lay upon the ground, flat on their backs; 
some huddled in a crouch, and there they sat

... supine in punishment.

In the Comedy, Dante and Virgil are in the third ring of the seventh circle, and the groups of souls gathered in flocks are those guilty of the three kinds of violence against God: the blasphemers lie on their backs; the usurers are crouching and the sodomites, omitted in the quotations, ceaselessly wander (Musa 119). Again, this quotation shows that Farah does not retrieve the moral judgment placed upon the souls, since the original reference to the sins is entirely removed. The focus is instead placed on the wretched human conditions, rather than on the divine contrappasso.

Similarly, the quotation before Part 2, taken from Canto XXIV (lines 88-93), underlines the same condition achieving a universalizing significance:

With all of Ethiopia

or all the land that borders the Red Sea-

so many, such malignant, pestilences.

Among this cruel and depressing swarm,

ran people who were naked, terrified,

with no hope of a refuge or a curse. (Links 147)

Canto XXIV deals with the seventh bolgia, a deep, narrow, concentric ditch or trench where thieves dwell, and Dante's allusion to Ethiopia is a reference to the significant number of serpents which inhabits the seventh bolgia - so many to overcome the number of snakes that live in the Ethiopian desert. Farah omits this hyperbole and manipulates the tercet to open up the novel's geopolitical context. Accordingly, he modifies the original last line ("with no hope of a hole or heliotrope") so to remove completely any reference to the snakes and the heliotrope, a supposed magical stone that could cure one from a snake's venom and give invisibility (Sapegno 270). Thus, the "land that borders the Red Sea" should be re-contextualized and understood, instead of Arabia, as Somalia, which engaged with Ethiopia an abiding territorial and political dispute over the Ogaden region, a territory comprising the eastern portion of Ethiopia predominantly populated by Somalis. The "people who were naked, terrified" represent, rather than Dantean thieves, the countless displaced people of that region, who have been experiencing war for decades and nowadays have "no hope of a refuge". Moreover, Farah aims to a more pragmatic reterritorialization of the Ogaden region by subverting the Orientalizing denotation that informs Dante's description (Alighieri 718).

While this example illustrates Farah's re-contextualization of Inferno, the closing lines of Chapter 23, the last before Part 3, shows the employment of an intertextual allusion unrelated to the epigraphs. The chapter ends with a sentence that subtly paraphrases lines 14l-2 of Inferno V: "Io venni men così com'io morisse / E caddi come corpo morto cade" (I fainted as if I had met my death / And then I fell as a dead body falls). Farah rewrites the lines describing Jeebleh while collapsing: "Finally he fell, forehead first, as though he were dead" (Links 241). It should also be noted that Jeebleh often faints, much like Dante the pilgrim during his journey through Hell. In the case of Inferno, Dante relates the loss of consciousness in response to terrifying, distressing or overwhelming situations. This shared physiological response between Jeebleh and Dante the pilgrim brings the comparison between the two characters to the fore along the intertextual axis and, moreover, suggests the attempts by Farah to deflate the sensationalism of the representations of war as conveyed by the mass media. The motif of fainting, therefore, allows Farah to emphasize his character's humanity and to reflect on the traumatic effect of violence unfolding an anti-sensationalist narrative (Mzali 98).

The abrupt and anticlimactic conclusion of Chapter 23 leads the reader to the quotation before Part 3, in which the lines from Canto XI (37-8; 40-1; 52-4) refer again to the inhabitants of Mogadishu in terms of a negative connotation:

... Murderers and those who strike in malice,

as well as plunderers and robbers ...

A man can set violent hands against

himself or his belongings ...

Now fraud, that eats away at every conscience,

is practiced by a man against another

who trusts in him, or one who has no trust. (Links 243) 
The fact that Farah himself-once again — assembled the terset, allowing the choice of the more relevant images to suit the novel's thematic spectrum, further supports the idea that the context in which Virgil exposes the structure of Hell is not relevant for the novel. Instead, the quotation fosters an all-embracing and evocative description of Mogadishans, without relating them to sins and punishments. Again, the symbolical parallel is drawn upon persons and objects rather than deities, since the sinners who have been violent against God are omitted. The word "belongings", in this case, acquires particular importance concerning the role of private property in Links. As Farah highlights, private houses, in particular, embody a critical problem in Mogadishu, where brutal expropriations and unlawful dispossession are means to achieve power and to establish one's control over an urban area or neighborhood. In terms of this perspective, the place that Bile and Seamus call "The Refuge" gains symbolical meaning, becoming an object, or a bene (a material good), which needs protection from depredation and human violence, "a place of peace and communal harmony" (Links 332).

Afterwards, Dante mentions fraud, which he relates to reason because of its premeditation and purpose to betray both friends and strangers (Sapegno 125). As already highlighted, during his stay in Mogadishu, Jeebleh seems to be surrounded by fraudulent sinners, as described in the last two lines of the quotation. Due to an overall situation of fraud, betrayal and half-truths, everyone should be looked at with suspicion, thus fostering the presence through the whole novel of a leitmotiv of mistrust. Whether the quotation mentioned above from Canto XI refers metaphorically to the inhabitants of Mogadishu as suggested through the whole novel, the following quote from Inferno XXVIII (lines 1-6) may be read, specifically, in relation to Chapter 26. The latter, as well as the canto, is committed to unfold the issue of how to represent horror (Sapegno 308):

Who, even with untrammeled words and many

attempts at telling, ever could recount

in full the blood and wounds that I now saw?

Each tongue that tried would certainly fall short

because the shallowness of both our speech

and intellect cannot contain so much.

This acknowledgement of being unable to describe exhaustively "the blood and wounds" bonds both Jeebleh and the pilgrim, "overwhelmed by the sight of mutilated, bloody shades" (Musa XXIX). Correspondingly, Chapter 26 tells of one of the crudest episodes of the novel, namely the account of the brutal American military intervention that occurred in 1993, culminating in the Battle of Mogadishu, which saw the downing of two helicopters and several casualties among the Somalis. The chapter is a retelling of the incident from Somalis' point of view, as both a counter-discourse to the dominant American narrative (Bystrom 413; Myers 138-9) and a counter-representation to that, mono-logic and sensationalistic, of the media (Mzali 96-8). The lines in the epigraph, which appear at the beginning of the canto, resonate in the very last part of Chapter 26 of the novel. Jeebleh plays the role of the listener, allowing two witnesses of the event to tell-like the souls of Hell revealing Dante their story-how the "horrific terror" occurred when the two Black Hawk helicopters were downed (Links 275). A five-and-a-half-year-old girl, daughter of the witness, suffered from damaged hearing because of the cacophonous noise of the helicopter, thus preventing her from being able to speak again (Links 272-3). The rotating blades and their razor-sharp noise resemble the "blade of the devil's sword" in Canto XXVIII. Farah describes Jeebleh in the act of visualizing the episode as if he becomes himself a witness of the event: "Jeebleh imagined the boy"; "Jeebleh was able to imagine" and he "could hear the sound in his own mind". However, Farah also deflates the sensationalism of the baleful account by preventing Jeebleh from imagining it: "Jeebleh stared, dumbfounded, unable to imagine the terror" (Links 275). In this case, therefore, the epigraph underscores the diegetic bond that connects Jeebleh to Dante, both unable to describe and imagine the horror.

The Epilogue further highlights this analogy, when the protagonist draws his conclusion upon the political view that underpins the Comedy and states that "his own story lay in a tarry of other's people tales, each with its own Dantean complexity" (331). This analogy encourages the comparison with the civil war that has been consuming Florence. In Mogadishu as well, the civil war is fought between groups who share the same religion, Islam, (as Catholicism linked the White and Black Guelphs in Florence), and who share the same language and place of abode. For Dante, the pope and the members of the Church were corrupted and immoral, seeking temporal power; political leaders, as well, were interested in their goods while ignoring their people's needs. Dante's conception of the correct politics implies that the church's sole mission should be to take care of religious matters rather than 
secular ones. In his times, both the emperor and the pope were neglecting their duties, resulting in the moral and political disorder he witnessed (Musa 162). Accordingly, Jeebleh seems to embrace this overall interpretation of Dante, since both religion and politics are accountable for the current hard reality of Somalia. Farah, by considering religion as one of the causes of the civil war, proposes a universalizing comparison between two usually antithetical cultural systems. In Links, indeed, the faults that Dante ascribes to the religious leaders of Christianity are re-centered onto the religious leaders of Islam, who share with the former the same longing for the temporal power to the detriment of transcendental, or spiritual, concerns. Religious and clan elders are to be blamed for the collapse of the state and the betrayal of their fellow Muslim Somalis, since they "were in cahoots with a cabal of warlords to share the gain they could make out of ordinary's people miseries" (Links 331). Jeebleh's understanding of the Somali context with regard to religion is then built upon Dante's ideas about religion, and the political role of the Church, as mentioned above, and supported in the Epilogue.

However, when Links concludes, the plot seems to lack a proper denouement, thus suggesting a relevant difference between the poem and the novel. The central events of the story - the kidnapping, the following release of Bile's niece, and the death of his arch-enemy Caloosha-happen without Jeebleh being present. The protagonist, furthermore, looks less resolute than after his arrival, in a sort of inverse trajectory to that of Dante the pilgrim. Accordingly, the line that rapidly closes the last quotation of the novel, from Canto XX (124-6; 130), matches the quickness of Jeebleh's departure from Mogadishu: "Jeebleh quit Mogadiscio the following morning (Links 334):

But let us go; Cain with his thorns already

is at the border of both hemispheres

and there, below Seville, touches the sea.

... Meanwhile we journeyed.

The extensive astronomical periphrasis used by Dante to express the moment of sunrise, when the moon reaches the horizon and is about to descend, parallels the final lines of Links: "He left as soon as he sensed the sun intruding on the horizon of his mind" (Links 334). Moreover, the periphrasis from Canto XX is used to express 6 a.m. (Musa 171), and the closing lines of Links show that the departure of Jeebleh occurred at the same time. After the days spent in Mogadishu, Jeebleh leaves as he senses the sun shining and "before the mist in his mind cleared" (Links 334). The enigmatic closing lines foster the characteristic indeterminacy of the novel and deflate the "classic denouncement $[\ldots]$ where the narrative ascribes deeds to doers" (Mzali 100). At the very end of the story, Jeebleh appears confused and insecure, as Dante's pilgrim at the beginning of his journey. In this sense, Farah subverts the incipit of the Comedy by representing his protagonist as "lost, unable or unwilling to decide which road to follow" (as the pilgrim "had lost the path that does not stray") (333). It seems that, in the end, Jeebleh is in need for a guide, a role that this time is performed by Dajaal, who offers to accompany him, hold him by the elbow, and show him the way. Like Dante with Virgil, Jeebleh cannot but "silently follow Dajaal" (333).

\section{Conclusion}

The analysis has highlighted the complex intertextual interplay at work in the novel Links. By providing a close cross-reading of both the Comedy and Links and an investigation of the practices of re-contextualization, subversion and allusions, the article has underscored the both opposing and converging tendencies between the two texts. In doing so, this study wishes to open up to potential future analysis along the comparative axis between Farah and other (modern, postmodern or postcolonial) authors who have engaged with Dante's oeuvre. As well, it may suggest moving Italian studies outside national borders, so as to retrieve the several literary influences that Italian literature has affected across the globe and, especially, in postcolonial contexts. Unfortunately, the almost total absence of studies about Farah in the field of Italian studies is remarkable, highlighting the latter's unwillingness to engage with postcolonial theory or grasp its relevance for contemporary writing in Italian and Italian influenced writing in a more world-wide context.

The article has shown how re-contextualization can produce a dialogue between a canonized work of literature such as the Comedy and a new present-day context. In this particular case, the civil-war and hell-like scenario of the 1990s Mogadishu trigger a fruitful comparison with both the representation of the suffering sinners in the netherworld, as imagined by Dante, and with the city of Florence, consumed by infighting, in the fourteenth century. This link between the poem and the novel, as shown, opens up to several interpretations and further com- 
parative readings, due to the breadth of allusions, references and images drawn into the novel from the Comedy. Among them, the special relationship between the narrator and the author, as well as between the paratext and the text, has been pivotal to show how intertextual practices operate in Links.

Farah decontextualizes the poem, omitting any references to its allegorical, historical, cultural and theological specificity, and then re-contextualizes it as a diegetic device to support the protagonist's understanding of the Somali conflict. The magnitude and universal scope of the Comedy is then both retrieved and recreated to position local Somali infighting on a wider cultural scale. This process, substantially achieved through the intertextual interplay between the two texts, allows Farah to move the context of Somalia from the periphery-where it is usually relegated - to the center of both literary and historical dynamics. However, the transcultural and transnational dialogue between the two texts, as shown, is also disturbed, as Farah implies the need for an adaptation and a re-contextualization. Accordingly, he assembles several tercets from Inferno by himself, as to underscore the significant influence of Dante's poem but, at the same time, to point out its incommensurability.

\section{Works Cited}

Abdi, A. Ali. "Education in Somalia: History, Destruction, and Calls for Reconstruction." Comparative Education vol. 34, no. 3, 1998, pp. 327-40. DOI: https://doi.org/10.1080/03050069828171.

Alden, Patricia \& Louis Tremaine. Nuruddin Farah. Twayne Publishers, 1999.

Alighieri, Dante. La Divina Commedia. Inferno, edited by Anna Maria Chiavacci Leonardi. Arnoldo Mondadori, 1991.

Barolini, Teodolinda. "Inferno 10: Love in Hell." Digital Dante. digitaldante.columbia.edu/dante/divine-comedy/inferno/ inferno-10/. Accessed 28 Apr. 2019.

."Inferno 14: We Are Our Own Hell: Sunt Lacrimae Rerum." Digital Dante. digitaldante.columbia.edu/dante/divine-comedy/ inferno/inferno-14/. Accessed 28 Apr. 2019.

Bystrom, Kerry. "Humanitarianism, Responsibility, Links, Knots." Interventions vol. 16, no. 3, 2014, pp. 405-23. DOI: https://doi. org/10.1080/1369801x.2013.798141.

Casanova, Pascale. The World Republic of Letters. Trans M. B. DeBevoise. Harvard, 2004.

Dodgson-Katiyo, Pauline. "The Rubble \& The Secret Sorrow", Diaspora \& Returns in Fiction, edited by Ernest N. Emenyonu and James Currey, 2016, pp. 67-81.

Eliot, T. S. "Ulysses, Order, and Myth." The Dial vol. 75, 1923, pp. 480-83.

Farah, Nuruddin. Links. Duckworth, 2005.

Frow, John. "Intertextuality and Ontology." Intertextuality. Theories and Practices, edited by Michael Worton and Judith Still. Manchester U P, 1990, pp. 46-55.

Garane, Garane. Il latte è buono. Cosmo Iannone, 2005.

Genette, Gérard. Paratexts: Thesholds of Interpretation. Trans. Jane E. Lewin. Cambridge U P, 1997. Palimpsests: Literature in the second degree. Trans. Channa Newman \& Claude Doubinsky. U of Nebraska P, 1997.

Hobbes, Thomas. Leviathan. Routledge, 2008.

Mandelbaum, Allen. Introduction to the Divine Comedy of Dante Alighieri. Bantam, 1984.

Mari, Lorenzo. Forme dell'interregno: Past Imperfect di Nuruddin Farah tra letteratura Post-coloniale e World Literature. Aracne, 2018.

Masterson, John. The Disorder of Things: A Foucauldian Approach to the Work by Nuruddin Farah. Wits U P, 2013.

Moolla, F. Fiona. Reading Nuruddin Farah, The Individual, the Novel e the Idea of Home. James Currey, 2014.

Musa, Mark. Dante's Inferno, The Indiana Critical Edition. Indiana U P, 1995.

Myers, Garth. African Cities: Alternative Visions of Urban Theory and Practice. Zed, 2011.

Mzali, Ines. "Wars of Representation: Metonymy and Nuruddin Farah's Links." College Literature vol. 37, no. 3, 2010, pp. 84-105. DOI: https://doi.org/10.1353/lit.0.0124.

Sapegno, Natalino. La Divina Commedia. Inferno. La Nuova Italia, 1993. 